U.S. Department of the Interior

U.S. Geological Survey

Prepared in cooperation with

U.S. Environmental Protection Agency

\title{
Transport of Suspended and Bedload Sediment at Eight Stations in the Coeur d'Alene River Basin, Idaho
}

Open-File Report 00-472

This report has not been reviewed for conformity with U.S. Geological Survey editorial standards.

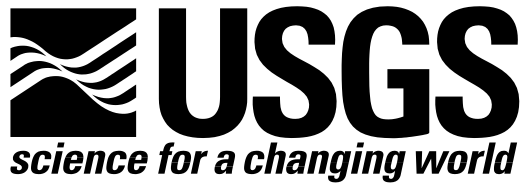




\section{Transport of Suspended and Bedload Sediment at Eight Stations in the Coeur d'Alene River Basin, Idaho}

By Gregory M. Clark and Paul F. Woods

Open-File Report 00-472

Prepared in cooperation with

U.S. Environmental Protection Agency

Boise, Idaho

2001 


\section{U.S. DEPARTMENT OF THE INTERIOR}

GALE A. NORTON, Secretary

\section{U.S. GEOLOGICAL SURVEY}

Charles G. Groat, Director

Any use of firm, trade, and brand names in this report is for identification purposes only and does not constitute endorsement by the U.S. Government.

Additional information can be obtained from:

District Chief

U.S. Geological Survey

230 Collins Road

Boise, ID 83702-4520

http://idaho.usgs.gov
This report is available online in PDF format and can be viewed using Adobe Acrobat Reader. The URL is:

http://idaho.usgs.gov/public/reports.html 


\section{CONTENTS}

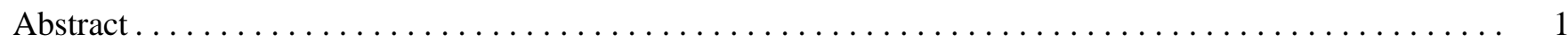

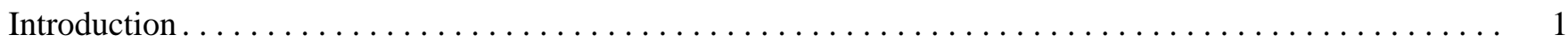

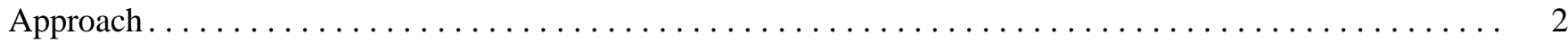

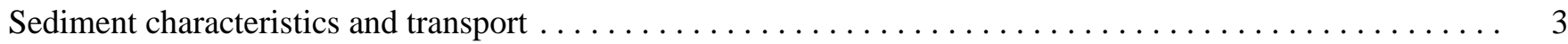

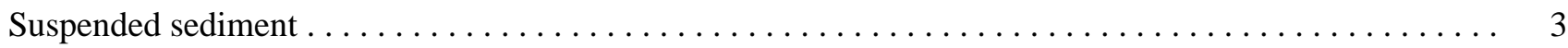

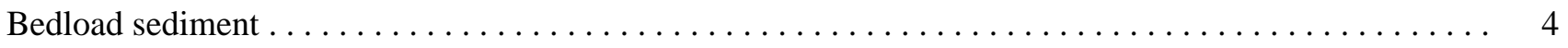

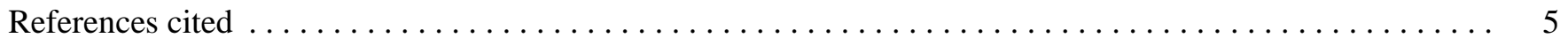

\section{FIGURES}

1. Map showing locations of eight stations measured for suspended- and bedload-sediment transport

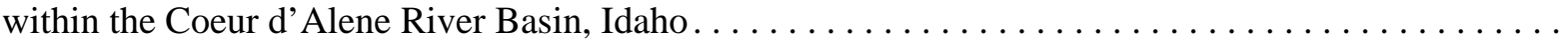

2-18. Graphs showing:

2. Sediment-transport curves for (A) total suspended sediment, and (B) suspended silt and clay

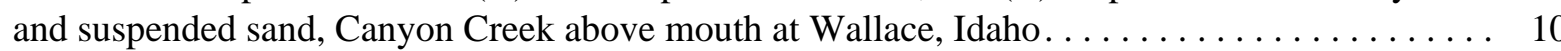

3. Sediment-transport curves for (A) total suspended sediment, and (B) suspended silt and clay and suspended sand, Ninemile Creek above mouth at Wallace, Idaho $\ldots \ldots \ldots \ldots \ldots \ldots \ldots .11$

4. Sediment-transport curves for (A) total suspended sediment, and (B) suspended silt and clay

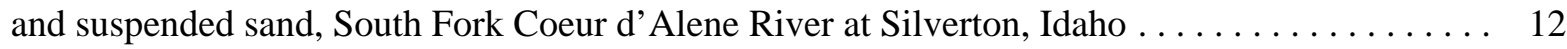

5. Sediment-transport curves for (A) total suspended sediment, and (B) suspended silt and clay and suspended sand, Pine Creek below Amy Gulch near Pinehurst, Idaho . . . . . . . . . 13

6. Sediment-transport curves for (A) total suspended sediment, and (B) suspended silt and clay and suspended sand, South Fork Coeur d'Alene River near Pinehurst, Idaho . . . . . . . . . . . 14

7. Sediment-transport curves for (A) total suspended sediment, and (B) suspended silt and clay and suspended sand, North Fork Coeur d'Alene River at Enaville, Idaho . . . . . . . . . . . 15

8. Sediment-transport curves for (A) total suspended sediment, and (B) suspended silt and clay and suspended sand, Coeur d'Alene River at Rose Lake, Idaho $\ldots \ldots \ldots \ldots \ldots \ldots \ldots \ldots$

9. Sediment-transport curves for (A) total suspended sediment, and (B) suspended silt and clay

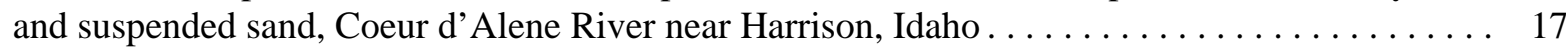

10. Sediment-transport curves for total suspended sediment at eight stations, Coeur d'Alene River

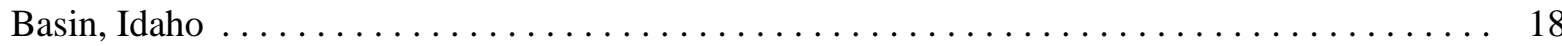

11. (A) Sediment-transport curves and (B) particle-size distribution of bedload sediment, Canyon Creek above mouth at Wallace, Idaho . . . . . . . . . . . . . . . . . . . . . . . .

12. (A) Sediment-transport curves and (B) particle-size distribution of bedload sediment, Ninemile Creek above mouth at Wallace, Idaho

13. (A) Sediment-transport curves and (B) particle-size distribution of bedload sediment, Pine Creek below Amy Gulch near Pinehurst, Idaho . . . . . . . . . . . . . . . . . . . .

14. (A) Sediment-transport curves and (B) particle-size distribution of bedload sediment, South

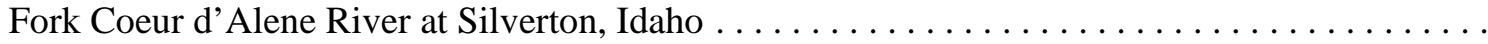

15. (A) Sediment-transport curves and (B) particle-size distribution of bedload sediment, South Fork Coeur d'Alene River near Pinehurst, Idaho . . 
16. (A) Sediment-transport curves and (B) particle-size distribution of bedload sediment, North Fork Coeur d' Alene River at Enaville, Idaho . . . . . . . . . . . . . . . . . . . . . . . . . . . . 24

17. (A) Sediment-transport curves and (B) particle-size distribution of bedload sediment, Coeur

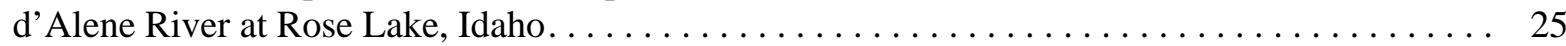

18. Sediment-transport curves for bedload sediment for seven stations, Coeur d'Alene River Basin, Idaho

\section{CONVERSION FACTORS AND ABBREVIATED UNITS}

\begin{tabular}{rll}
\hline Multiply & By & To obtain \\
\hline cubic foot per second $\left(\mathrm{ft}^{3} / \mathrm{s}\right)$ & 0.02832 & cubic meter per second \\
foot $(\mathrm{ft})$ & 0.3048 & meter \\
inch (in.) & 2.540 & centimeter \\
mile $(\mathrm{mi})$ & 1.609 & kilometer \\
square mile $\left(\mathrm{mi}^{2}\right)$ & 2.590 & square kilometer \\
ton per day $(\mathrm{t} / \mathrm{d})$ & 0.9072 & metric ton per day \\
\hline
\end{tabular}

\section{Abbreviated units:}

$\mu \mathrm{m} \quad$ micrometer

mm millimeter 


\title{
Transport of Suspended and Bedload Sediment at Eight Stations in the Coeur d'Alene River Basin, Idaho
}

\author{
By Gregory M. Clark and Paul F. Woods
}

\section{Abstract}

The Remedial Investigation/Feasibility Study conducted by the U.S. Environmental Protection Agency within the Spokane River Basin of northern Idaho and eastern Washington included extensive data-collection activities to determine the nature and extent of trace-element contamination within the basin. As part of the investigation, the U.S. Geological Survey designed and implemented a sampling program to assess sediment transport in the Coeur d'Alene River Basin. Suspended and bedload sediments were sampled at four stations at or near base flow and at eight stations during low, moderate, and high discharge conditions between February 1999 and April 2000.

The concentrations and loads of suspended and bedload sediment at all stations were directly related to stream discharge. To quantify these relationships, a power function was used to develop sediment-transport curves at all stations. Although the transport curves for most of the stations indicate a good log-log relationship between stream discharge and suspended- and bedload-sediment discharge, there was a fair amount of scatter about the best-fit regression at most stations. For suspended-sediment discharge, the scatter can be primarily attributed to a hysteresis effect in the concentration of suspended sediment as stream discharge rises and falls. The effects of hysteresis on bedload-sediment discharge were difficult to assess because of a paucity of samples collected over the stream hydrograph.

At most of the stations, and at the stream discharges sampled, the transport characteristics for fine- and sand-sized suspended sediment were similar. However, at the two main-stem Coeur
d'Alene River stations, Rose Lake and Harrison, the suspended-sediment load was primarily composed of fine-grained sediment at stream discharges of less than 15,000 cubic feet per second. These two stations are characterized by relatively slow water velocities, which appear to be insufficient to transport sand-sized sediment at lower stream discharge.

At most of the stations, and at the stream discharges sampled, the bedload was primarily composed of material greater than 2 millimeters in diameter, the break between sand and gravel. A predominance of sand-sized bedload was noted at only a few stations, and generally only during low stream discharge. The particle-size distribution of bedload sediment at most stations became proportionately coarser as stream discharge increased. During the peak of snowmelt runoff for water years 1999 and 2000, gravel-sized material between 2 and 64 millimeters in diameter comprised more than 70 percent of the bedload transport at most stations. However, at the station on the Coeur d'Alene River at Rose Lake, the bedload was predominantly composed of fine-grained material of less than 1 millimeter in diameter for all measured stream discharges. The slow water velocities at Rose Lake accounted for the predominance of fine-grained sediment transport.

\section{INTRODUCTION}

Mining and ore-processing activities conducted over the past 100 years in the South Fork Coeur d'Alene River Basin have produced extensive deposits of trace-element-contaminated sediments throughout the South Fork Coeur d'Alene River valley and its tributaries, the channel and flood plain of the main stem 
Coeur d'Alene River, and the lakebed of Coeur d'Alene Lake. Snowmelt runoff and occasional floods continue to transport and redistribute trace-elementcontaminated sediments throughout the $6,680-\mathrm{mi}^{2}$ Spokane River Basin of northern Idaho and eastern Washington (fig. 1, back of report).

The U.S. Environmental Protection Agency (EPA) has recently initiated a Remedial Investigation/Feasibility Study (RI/FS) of the Spokane River Basin under the authority of the Comprehensive Environmental Response, Compensation, and Liability Act of 1980 (CERCLA), which requires EPA to evaluate contaminant release, fate, and transport. The Remedial Investigation phase involves data collection to characterize site conditions, development of conceptual models, determination of the nature and extent of trace-element contamination, and risk assessment for human health and the environment. The development and evaluation of remedial action alternatives is the focus of the Feasibility Study. In March of 1998, the EPA asked the U.S. Geological Survey (USGS) to identify hydrologic and water-quality studies the USGS might perform in support of the RI/FS of the Spokane River Basin. The study described in this report was conducted by USGS as Task 7 (evaluation of suspended- and bedload-sediment transport within the Coeur d'Alene River Basin and affected areas, Subtask B) of Interagency Agreement DW14957278-01-0 with EPA.

The objective of the study was to provide an assessment of sediment-transport characteristics within the Coeur d'Alene River Basin. Such an assessment was needed to estimate sediment concentrations and transport rates and to characterize sediment transport as related to particle size and discharge conditions. Suspended and bedload sediments were sampled at eight USGS gaging stations between February 1999 and April 2000.

\section{APPROACH}

Listed below are USGS station numbers and names for the eight stations where suspended and bedload sediments were sampled for this study. The number in parentheses preceding the USGS station number indicates the locations of the stations on figure 1 .

(2) 12413150 South Fork Coeur d'Alene River at Silverton, Idaho

(4) 12413470 South Fork Coeur d'Alene River near Pinehurst, Idaho
(5) 12413125 Canyon Creek above mouth at Wallace, Idaho

(8) 12413030 Ninemile Creek above mouth at Wallace, Idaho

(13) 12413445 Pine Creek below Amy Gulch near Pinehurst, Idaho

(16) 12413000 North Fork Coeur d'Alene River at Enaville, Idaho

(18) 12413810 Coeur d'Alene River at Rose Lake, Idaho

(19) 12413860 Coeur d'Alene River near Harrison, Idaho

Suspended- and bedload-sediment samples were collected at four different discharge conditions. Baseflow discharge was sampled at South Fork Coeur d'Alene River near Pinehurst, North Fork Coeur d'Alene River at Enaville, Coeur d'Alene River at Rose Lake, and Coeur d'Alene River near Harrison. The other three discharge conditions (low, moderate, and high) were sampled at the eight stations during nonsteady discharges (storm hydrographs). During the low, moderate, and high discharge conditions, sampling was conducted once on the ascending limb, once at the peak, and once on the descending limb. Discharge measurements in support of the sediment sampling were made using standardized USGS methods for collection of streamflow data, computation of discharge, and quality assurance procedures which are thoroughly described in six USGS Techniques of Water-Resources Investigations Reports (Buchanan and Somers, 1968, 1969; Riggs, 1968; Carter and Davidian, 1968; Kennedy, 1983, 1984).

Suspended-sediment samples were collected using width- and depth-integrating techniques to obtain representative samples. When streams were wadeable, suspended-sediment samples were collected using a DH-81 handheld sampler. When streams were not wadeable, samples were collected using a D-74 or D-77 reel-mounted sampler. Edwards and Glysson (1988) provide detailed descriptions of the methods of collection and different sampling devices used to sample suspended sediment.

Bedload samples were collected between 3 and 10 times at each station using a Helley-Smith sampler with a 3.0-in. by 3.0-in. nozzle suspended from a bridge crane. Bedload samples were collected using equal-width increment sampling methods described in Edwards and Glysson (1988). This method involves dividing and sampling the stream channel in evenly 
spaced sections to accurately represent bedload transport across the entire channel. Duplicate samples were collected during each station visit and were analyzed separately. During data analysis, the results for the duplicate samples were reported as an average.

Suspended- and bedload-sediment samples were analyzed at the USGS Cascades Volcano Observatory's sediment laboratory. Suspended-sediment samples were analyzed for total concentration and particle-size fraction less than $63 \mu \mathrm{m}$. Bedload-sediment samples were analyzed for total mass and particle size from $63 \mu \mathrm{m}$ to $64 \mathrm{~mm}$. Guy (1969) provides a detailed description of the techniques used for the analysis of sediment samples.

\section{SEDIMENT CHARACTERISTICS AND TRANSPORT}

Streams transport sediment by maintaining the finer particles in suspension with turbulent currents and by rolling or skipping coarser particles along the streambed. The discharge of fine-grained particles is typically controlled by the available supply of such particles with the supply often less than the stream can transport (Colby, 1956). These fine-grained sediments generally move downstream at about the same velocity as the water. In contrast to fine-grained sediments, the supply of coarser grained sediments in streams is generally greater than the stream can transport. Thus, the discharge of coarser grained sediments is typically controlled by the ability of the stream to transport them (Guy, 1970). The sediment that moves on or near the stream bottom by sliding, rolling, or bouncing is termed bedload (Edwards and Glysson, 1988). Bedload may move only occasionally and remain at rest much of the time. As a result of these differences in transport mechanisms, a great deal of variation can be expected in the concentration and grain-size characteristics of sediments at different locations in a stream and with changes in stream discharge. To evaluate the effects of stream discharge on sediment characteristics, transport and sediment-size distribution curves were developed to describe the relationship between sediment discharge and stream discharge. Results are described in the following sections.

\section{Suspended Sediment}

In general, the concentrations of both fine- and coarse-grained sediments within a stream channel increase with increasing stream discharge (Edwards and Glysson, 1988). To describe the relationship between suspended-sediment discharge and stream discharge, a power function was used to develop transport curves for sediment discharge. This technique involves fitting a curve to points on a scatter diagram as described in Colby (1956). On a log-log scale, stream discharge at the time of sample collection is plotted as the independent variable with suspended-sediment discharge as the dependent variable. Suspended-sediment discharge, in tons per day, was calculated using the following equation:

$$
Q_{s}=Q_{w} \times C_{s} \times k
$$

where

$Q_{S}$ is suspended-sediment discharge, in tons per day;

$Q_{w}$ is stream discharge, in cubic feet per second;

$C_{S}$ is suspended-sediment concentration, in milligrams per liter; and

$k$ is a conversion factor of 0.0027 .

The best-fit equation that is derived from the relationship between stream discharge and suspendedsediment discharge can be used to estimate an average suspended-sediment discharge for a given stream discharge over a period of a day, month, or year. Because the estimated value is an average, computed sediment discharges during short time periods are subject to appreciable error because of variations in the relation between stream discharge and sediment discharge. This type of error should be generally compensating as the time period of estimation is increased.

The relation between stream discharge and suspended-sediment discharge for the eight stations measured in the Coeur d'Alene River Basin is shown in figures 2-9 (back of report). Although the best-fit regression line at most of the stations indicates a good log-log relationship between stream discharge and total suspended-sediment discharge (correlation coefficient, $\mathrm{r}$, ranged from 0.82 to 0.97 ), there is a fair amount of scatter about the regression line at all of the stations. This scatter can be partly attributed to a hysteresis effect in the concentration of suspended-sediment as 
stream discharge rises and falls. When stream discharge is rising, materials stored within the stream channel or in riparian and terrestrial zones become mobile as they are subjected to increased stream velocities. The magnitude of the hysteresis effect can be affected by antecedent conditions as well as the magnitude of the discharge event generating hysteresis. Because of the mobilization of stored sediments, samples collected during the rising part of the stream hydrograph typically have larger concentrations of suspended sediment as compared to samples collected at similar discharge during the falling part of the stream hydrograph. In figures 2-9, points to the left of the best-fit regression line generally represent samples collected when stream discharge was rising; points to the right of the line generally represent samples collected when stream discharge was falling. Figures 2 and 3 illustrate the effect of hysteresis on suspendedsediment discharge in Canyon and Ninemile Creeks. At both stations, samples collected during rising stream discharge had more suspended-sediment transport as compared to samples collected during falling stream discharge. Hysteresis is evident as two loops in the stream-sediment discharge relationship during the snowmelt events occurring from March 15 to March 29, 1999, and from March 29 to May 31, 1999.

Comparisons of the suspended-sediment curves for the eight stations analyzed in the Coeur d'Alene River Basin are shown in figure 10 (back of report). Ninemile Creek, Pine Creek, and the North Fork Coeur d'Alene River at Enaville tend to have steeper slopes to their sediment-transport curves as compared to stations on Canyon Creek and the South Fork and main-stem Coeur d'Alene Rivers. Steeper slopes indicate a more dramatic response in the transport of suspended sediment to changes in stream discharge. An examination of figure 10 also indicates that at the stream discharges measured, Ninemile Creek transports significantly more suspended sediment per unit discharge than does Canyon Creek. Similarly, the South Fork Coeur d'Alene River at Silverton transports significantly more suspended sediment per unit discharge as compared to the downstream site at Pinehurst. This is due in part to the intervening inflow from Pine Creek, which dilutes suspended-sediment concentrations in the South Fork Coeur d'Alene River. Differences in channel geometry also explain part of the sediment-transport differences between the Silverton and Pinehurst stations; the smaller cross-sectional area at the Silverton station produces higher, more erosive stream velocities. A large decrease in suspended-sediment transport per unit discharge also occurs between the Pinehurst station and the two main-stem Coeur d'Alene River stations at Rose Lake and Harrison. Again, dilutional inflow from the North Fork Coeur d'Alene River explains part of the decrease. Additionally, deposition of sediment within the main-stem Coeur d'Alene River is engendered by the backwater conditions created by waterlevel management of Coeur d'Alene Lake.

The relationship between the fraction of suspended-sediment discharge composed of fines (particles of $63 \mu \mathrm{m}$ diameter and smaller) and the fraction composed of sand at the eight stations is also shown in figures 2-9. For most of the stations, there is not a large difference in the transport characteristics of fine- and sand-sized material. At the Rose Lake and Harrison stations, however, the transport curves indicate that when stream discharge is less than about $15,000 \mathrm{ft}^{3} / \mathrm{s}$, most of the suspended sediment is composed of fine-grained material (figs. 8 and 9). These two stations are characterized by relatively slow water velocities, which appear to be insufficient to transport sand-sized sediment at lower stream discharge. Not until stream discharge approaches about $20,000 \mathrm{ft}^{3} / \mathrm{s}$ does the discharge of sand-sized material at Rose Lake and Harrison become equivalent to the discharge of fine-grained material.

\section{Bedload Sediment}

Unlike suspended-sediment transport, transport of bedload material is not always evident. For instance, only three stations (South Fork Coeur d'Alene River at Silverton and near Pinehurst and Pine Creek) had measurable bedload during low-flow sampling from March 15-16, 1999. In the main-stem Coeur d'Alene River at Rose Lake and near Harrison, bedload transport was either negligible or nonexistent on most of the sampling dates. For the Coeur d'Alene River near Harrison, a bedload-transport curve could not be developed. When bedload discharge does occur, it is often extremely variable both spatially within the stream channel and temporally during steady stream-discharge conditions. Because of this variability, transport curves fitted for bedload transport generally have a larger degree of uncertainty than do curves for suspendedsediment transport. To develop transport curves for bedload discharge in the Coeur d'Alene River Basin, 
the following equation (Edwards and Glysson, 1988) was used:

$$
Q_{b}=(k \times W \times M) / T
$$

where

$Q_{b}$ is bedload discharge, in tons per day;

$k$ is a conversion factor of 0.381 ;

$W$ is total stream width, in feet;

$M$ is total mass of bedload sample collected from all sections, in grams; and

$T$ is the total time the sampler was on the bed, in seconds.

As with suspended sediment, the best-fit equations shown in figures 11-17 (back of report) can be used to estimate average bedload discharge for a given period of time. However, because of the paucity of samples at some stations and the variability at most of the stations, the bedload-discharge estimates obtained would be subject to appreciable error. The range in correlation coefficients for the bedload-transport equations was from 0.52 to 0.98 . Additional samples collected at higher stream discharge would provide better definition and more confidence in the bedload-discharge transport curves.

At all stations, the largest measured bedload discharge occurred during large stream discharge at the end of May 1999 or mid-April 2000. The largest measured bedload discharge was about $2,700 \mathrm{t} / \mathrm{d}$ at a stream discharge of $20,000 \mathrm{ft}^{3} / \mathrm{s}$ on April 14, 2000, in the North Fork Coeur d'Alene River at Enaville. Within and between station comparisons of the bedload-sediment rating curves (fig. 18, back of report) indicate similarities and differences with the curves for suspended sediment (fig. 10). Similar to the transport of suspended sediment, the transport of bedload sediment in Ninemile Creek, Pine Creek, and the North Fork Coeur d'Alene River at Enaville appear especially sensitive to changes in stream discharge as evidenced by the steep slope of their transport curves. Also similar to the transport of suspended sediment, Ninemile Creek transported significantly more bedload sediment per unit discharge during 1999 than did Canyon Creek. In contrast to the transport of suspended sediment, Pine Creek transported significantly more bedload sediment per unit discharge as compared to stations on the South Fork Coeur d'Alene River at Silverton and near Pinehurst.
In general, the particle-size distribution of bedloadsediment samples at most stations was proportionately coarser as stream discharge increased (figs. 11-17). At most of the stations and for most of the stream discharges sampled, the bedload was primarily composed of material greater than $2 \mathrm{~mm}$ in diameter, the break between sand and gravel (Guy, 1969). A predominance of sand-sized and smaller bedload was noted at only a few stations, and generally only during low stream discharge. During the peak of snowmelt runoff, gravelsized material between 2 and $64 \mathrm{~mm}$ diameter comprised more than 70 percent of the bedload transport at all stations except Canyon Creek and the Coeur d'Alene River at Rose Lake. At all of the stream discharges measured, the bedload in the Coeur d'Alene River at Rose Lake was predominantly composed of fine-grained material less than $1 \mathrm{~mm}$ in diameter (fig. 17).

\section{REFERENCES CITED}

Buchanan, T.J., and Somers, W.P., 1968, Stage measurements at gaging stations: U.S. Geological Survey Techniques of Water-Resources Investigations, book 3, chap. A7, 28 p.

1969, Discharge measurements at gaging stations: U.S. Geological Survey Techniques of Water-Resources Investigations, book 3, chap. A8, 65 p.

Carter, R.W., and Davidian, J., 1968, General procedure for gaging streams: U.S. Geological Survey Techniques of Water-Resources Investigations, book 3, chap. A6, 13 p.

Colby, B.R., 1956, Relationship of sediment discharge to streamflow: U.S. Geological Survey Open-File Report, $170 \mathrm{p}$.

Edwards, T.K., and Glysson, G.D., 1988, Field methods for measurement of fluvial sediment: U.S. Geological Survey Open-File Report 86-531, $118 \mathrm{p}$.

Guy, H.P., 1969, Laboratory theory and methods for sediment analysis: U.S. Geological Survey Techniques of Water-Resources Investigations, book 5, chap. C1, $58 \mathrm{p}$. 1970, Fluvial sediment concepts: U.S. Geological Survey Techniques of Water-Resources Investigations, book 3 , chap. $\mathrm{C} 1,55 \mathrm{p}$.

Kennedy, E.J., 1983, Computation of continuous records of streamflow: U.S. Geological Survey 
Techniques of Water-Resources Investigations, book 3, chap. A13, 53 p.

1984, Discharge ratings at gaging stations:

U.S. Geological Survey Techniques of Water-

Resources Investigations, book 3, chap. A10, 59 p.
Riggs, H.C., 1968, Some statistical tools in hydrology: U.S. Geological Survey Techniques of Water-

Resources Investigations, book 4, chap. A1, 30 p. 
Figures 1-18 



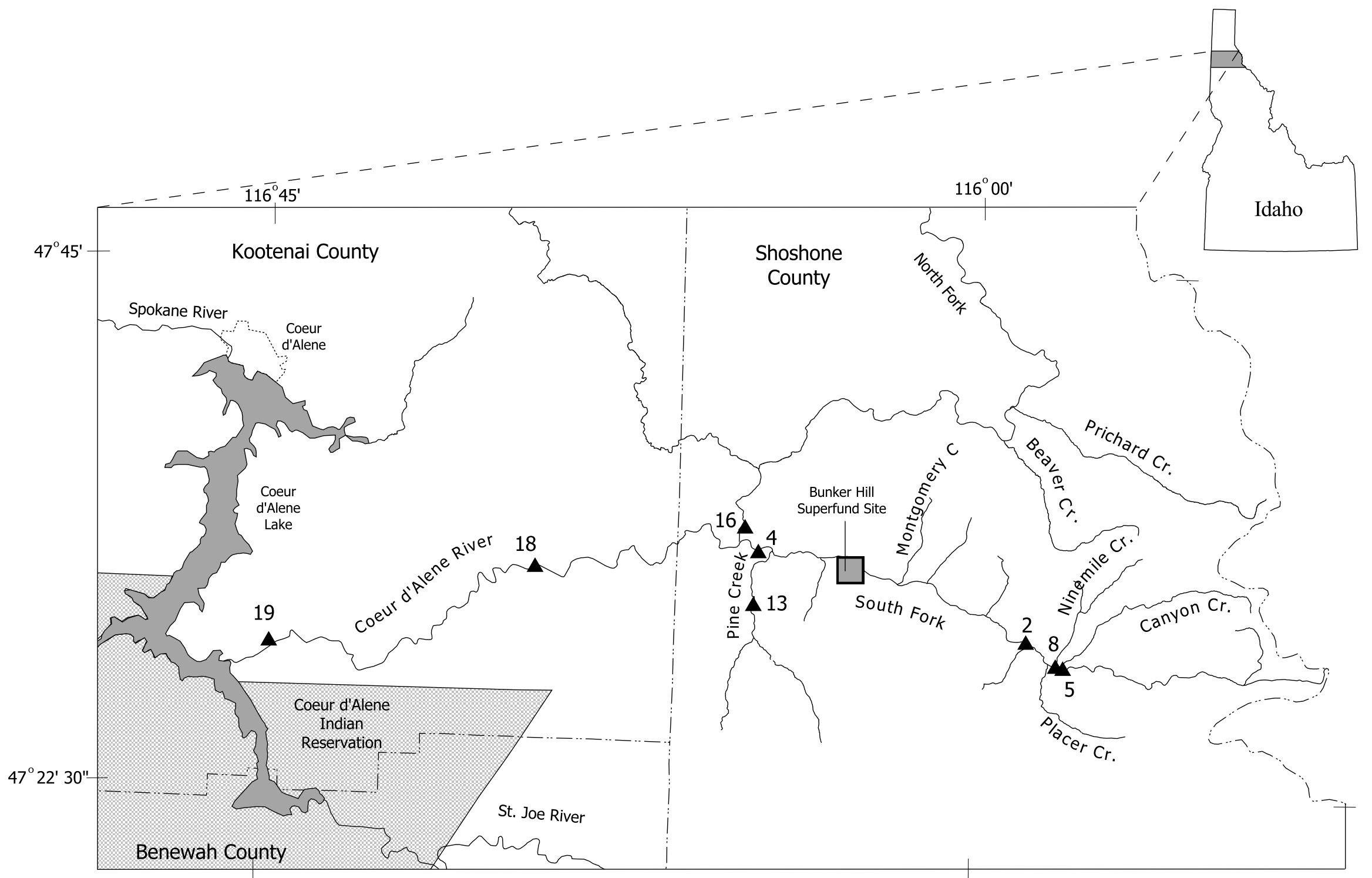

Base from U.S. Geological Survey digital data, 1:100,000, 1999 Albers Equal-Area projection standard parallels $43^{\circ} 30^{\prime}, 47^{\circ} 30^{\prime}$, and $-114^{\circ} 00^{\prime}, 41^{\circ} 45^{\prime}$

no false easting or false northing.

Figure 1. Locations of eight stations measured for suspended- and bedload-sediment transport within Coeur d'Alene River Basin, Idaho. 

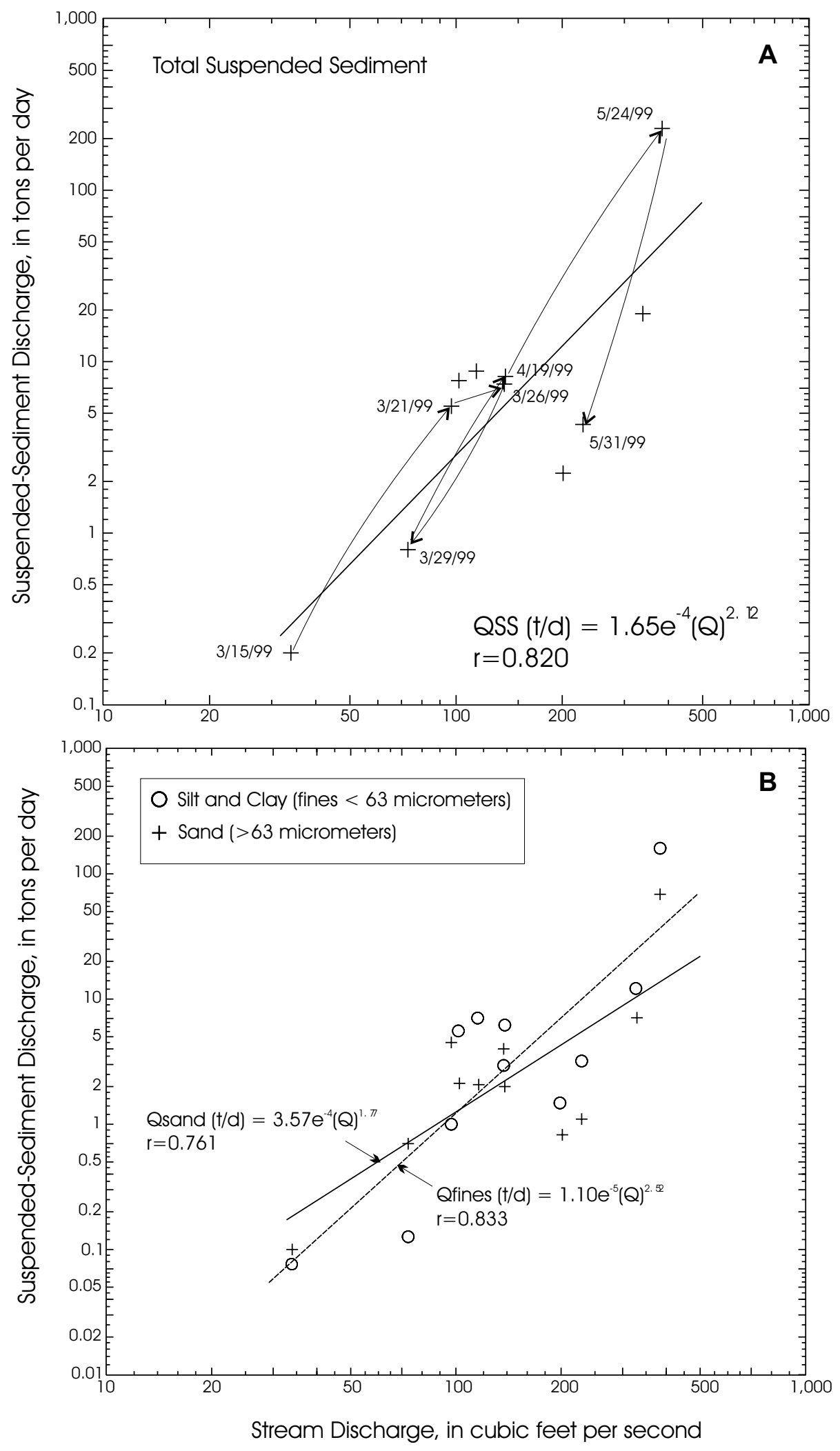

Figure 2. Sediment-transport curves for (A) total suspended sediment, and $(B)$ suspended silt and clay and suspended sand, Canyon Creek above mouth at Wallace, Idaho 

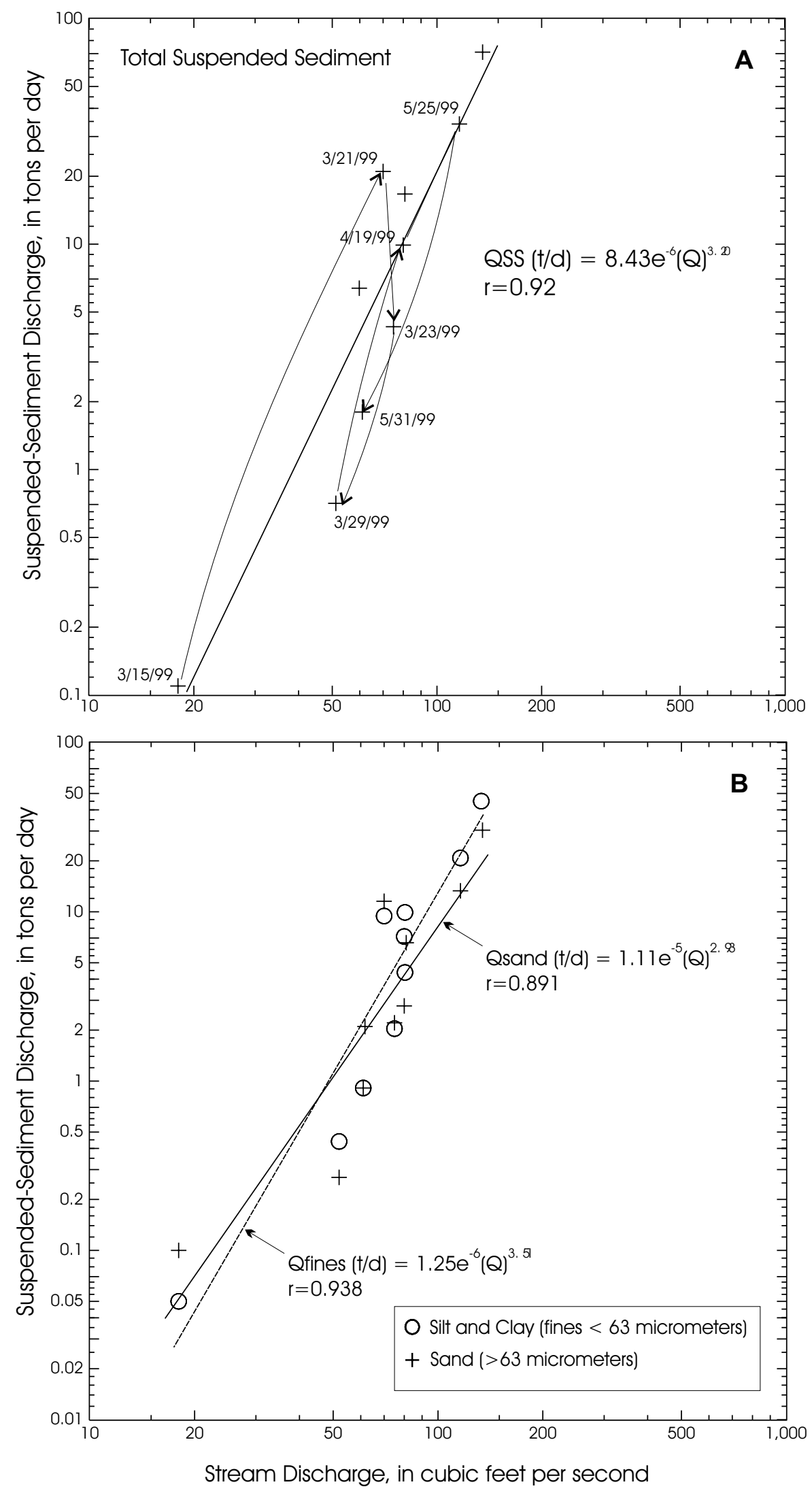

Figure 3. Sediment-transport curves for (A) total suspended sediment, and $(B)$ suspended silt and clay and suspended sand, Ninemile Creek above mouth at Wallace, Idaho 

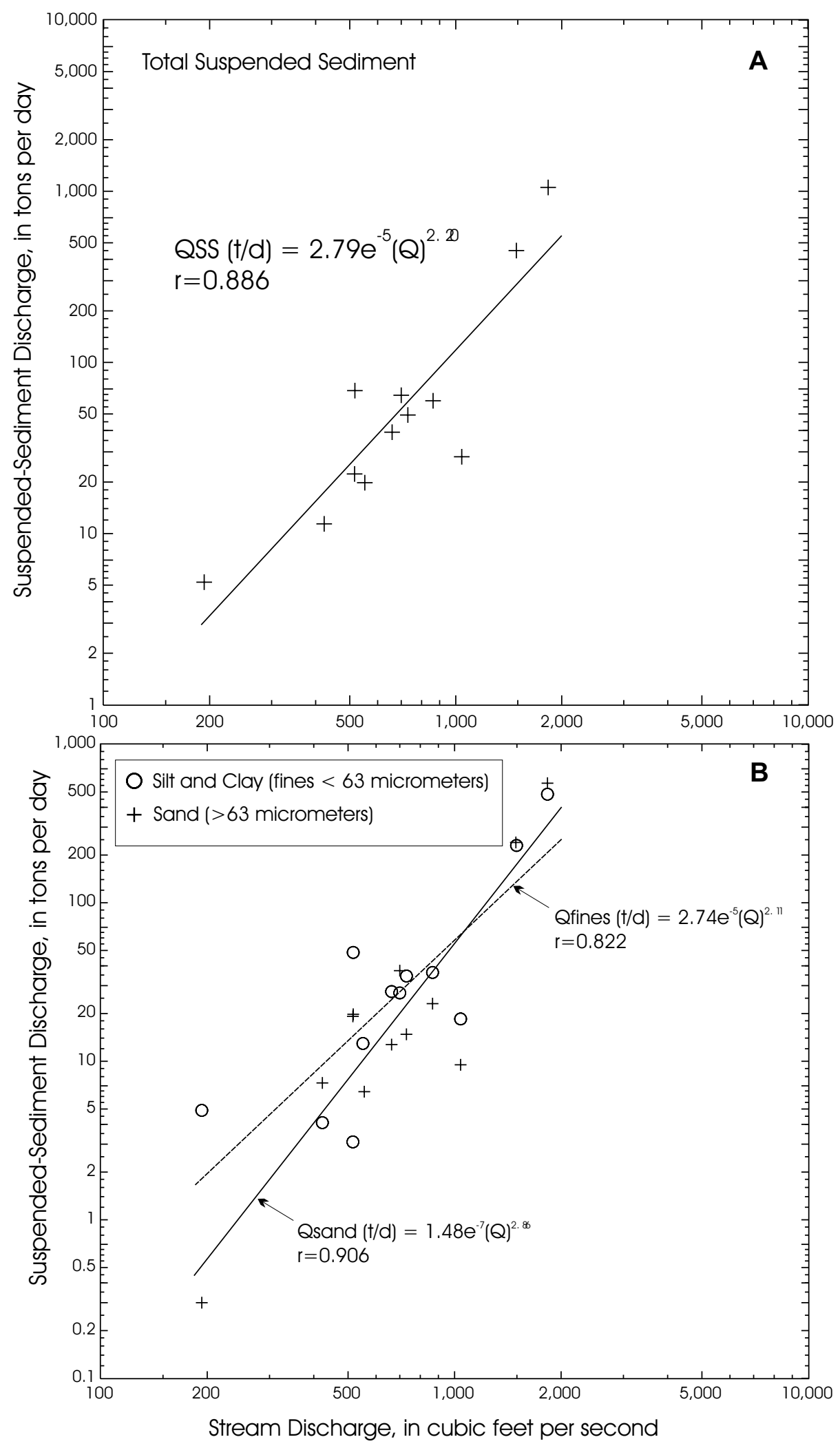

Figure 4. Sediment-transport curves for (A) total suspended sediment, and $(B)$ suspended silt and clay and suspended sand, South Fork Coeur d'Alene River at Silverton, Idaho 

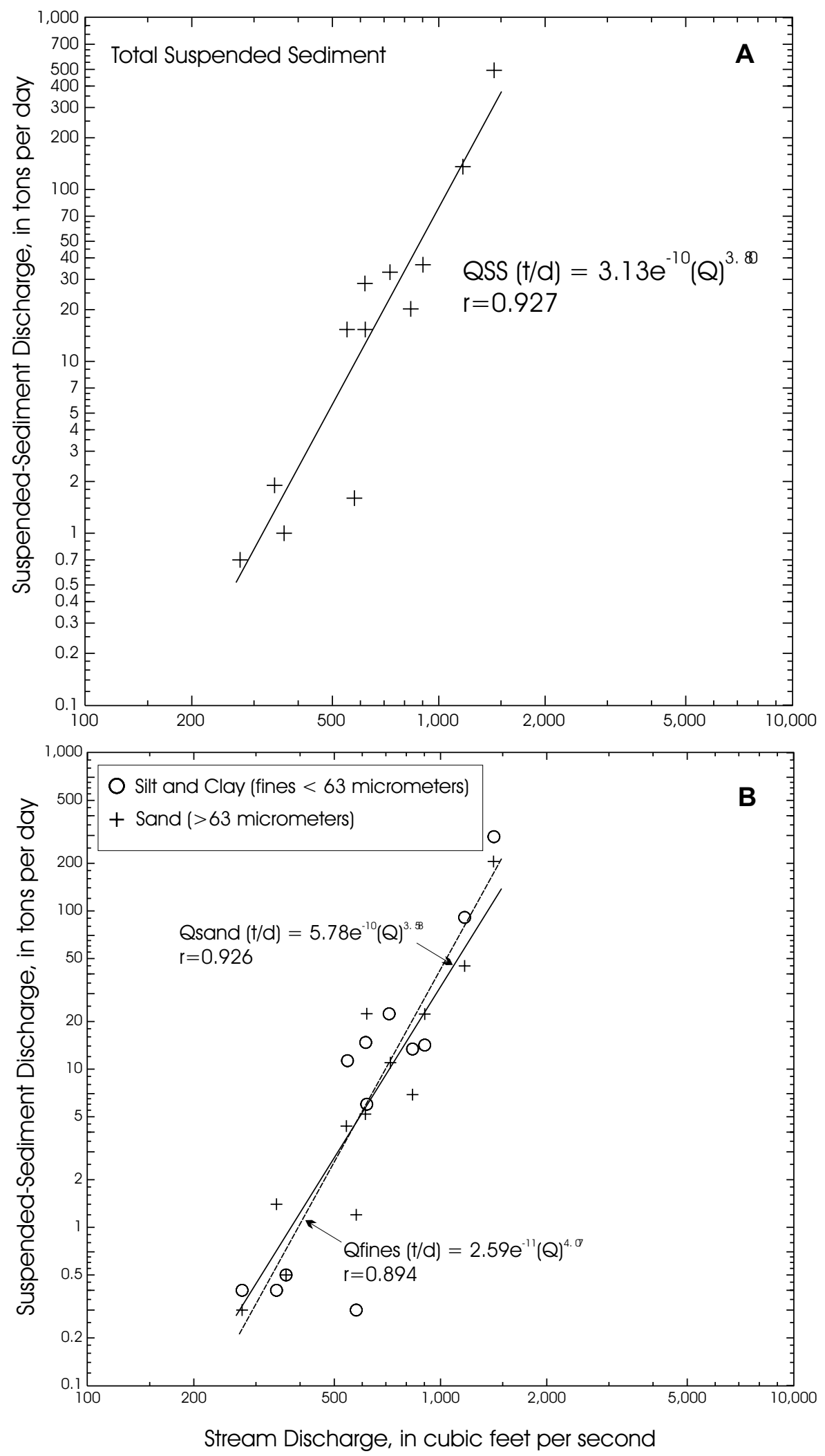

Figure 5. Sediment-transport curves for (A) total suspended sediment, and (B) suspended silt and clay and suspended sand, Pine Creek below Amy Gulch near Pinehurst, Idaho 

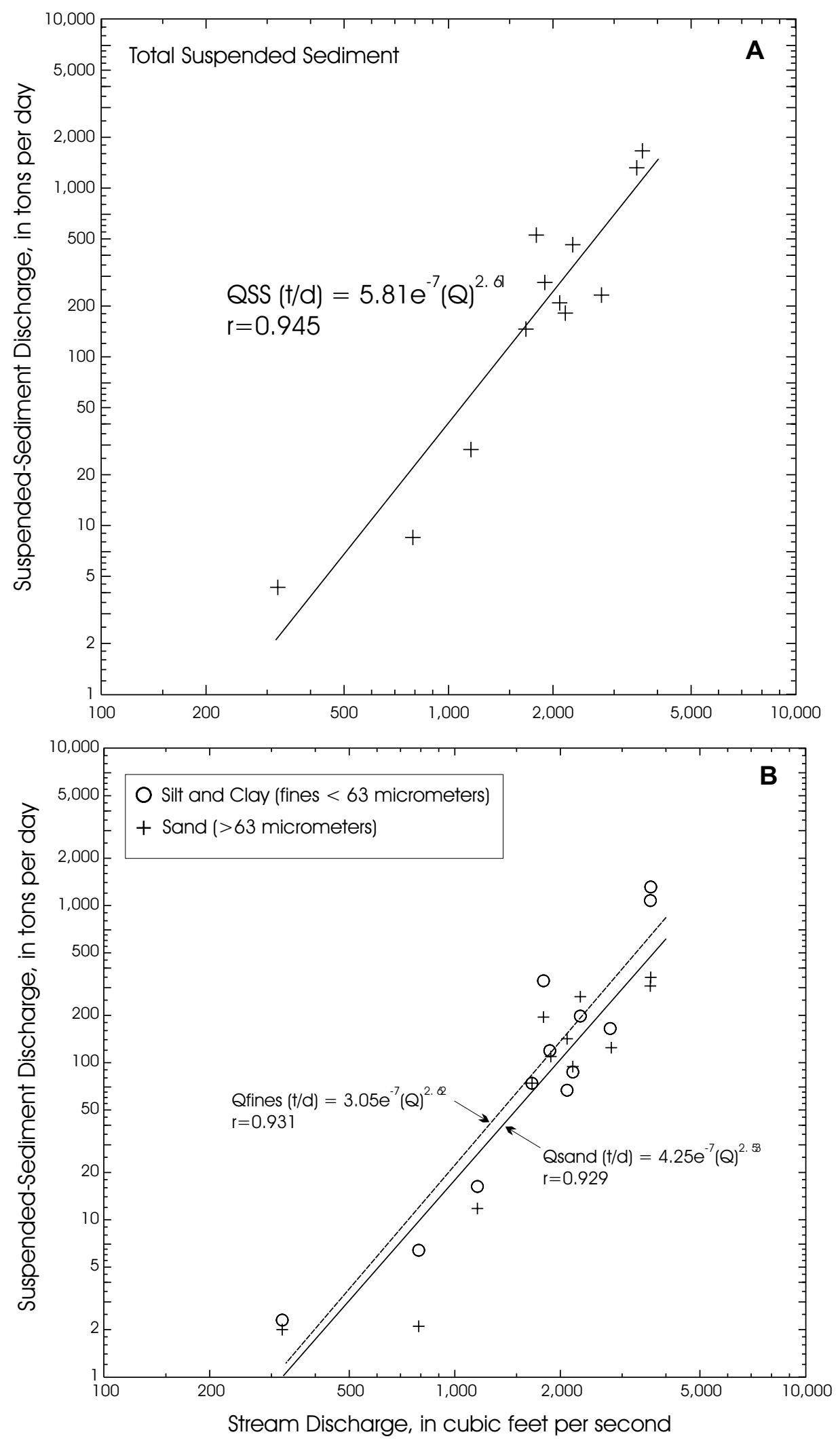

Figure 6. Sediment-transport curves for (A) total suspended sediment, and (B) suspended silt and clay and suspended sand, South Fork Coeur d'Alene River near Pinehurst, Idaho 

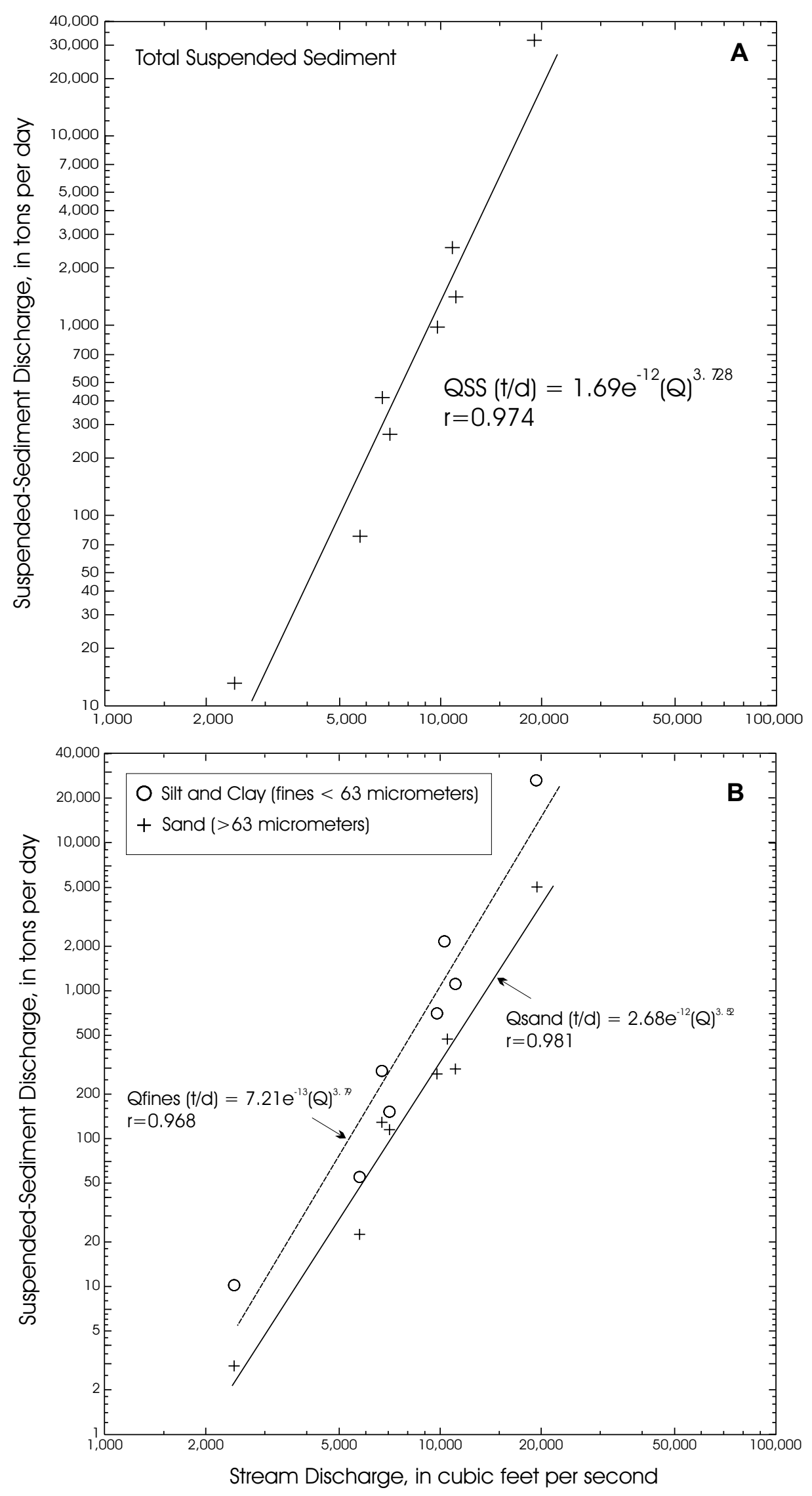

Figure 7. Sediment-transport curves for (A) total suspended sediment, and $(B)$ suspended silt and clay and suspended sand, North Fork Coeur d'Alene River at Enaville, Idaho 

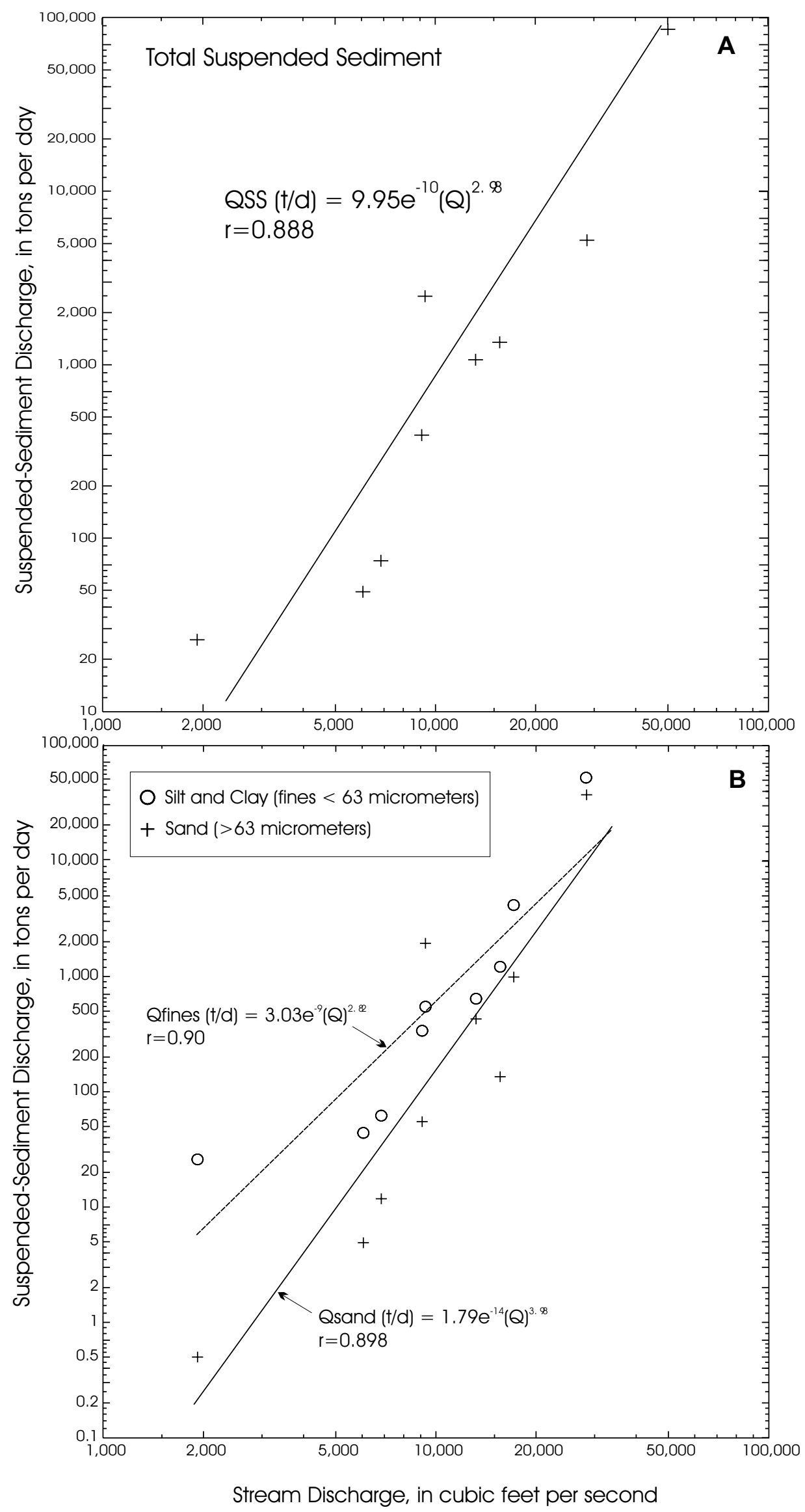

Figure 8. Sediment-transport curves for (A) total suspended sediment, and (B) suspended silt and clay and suspended sand, Coeur d'Alene River at Rose Lake, Idaho 

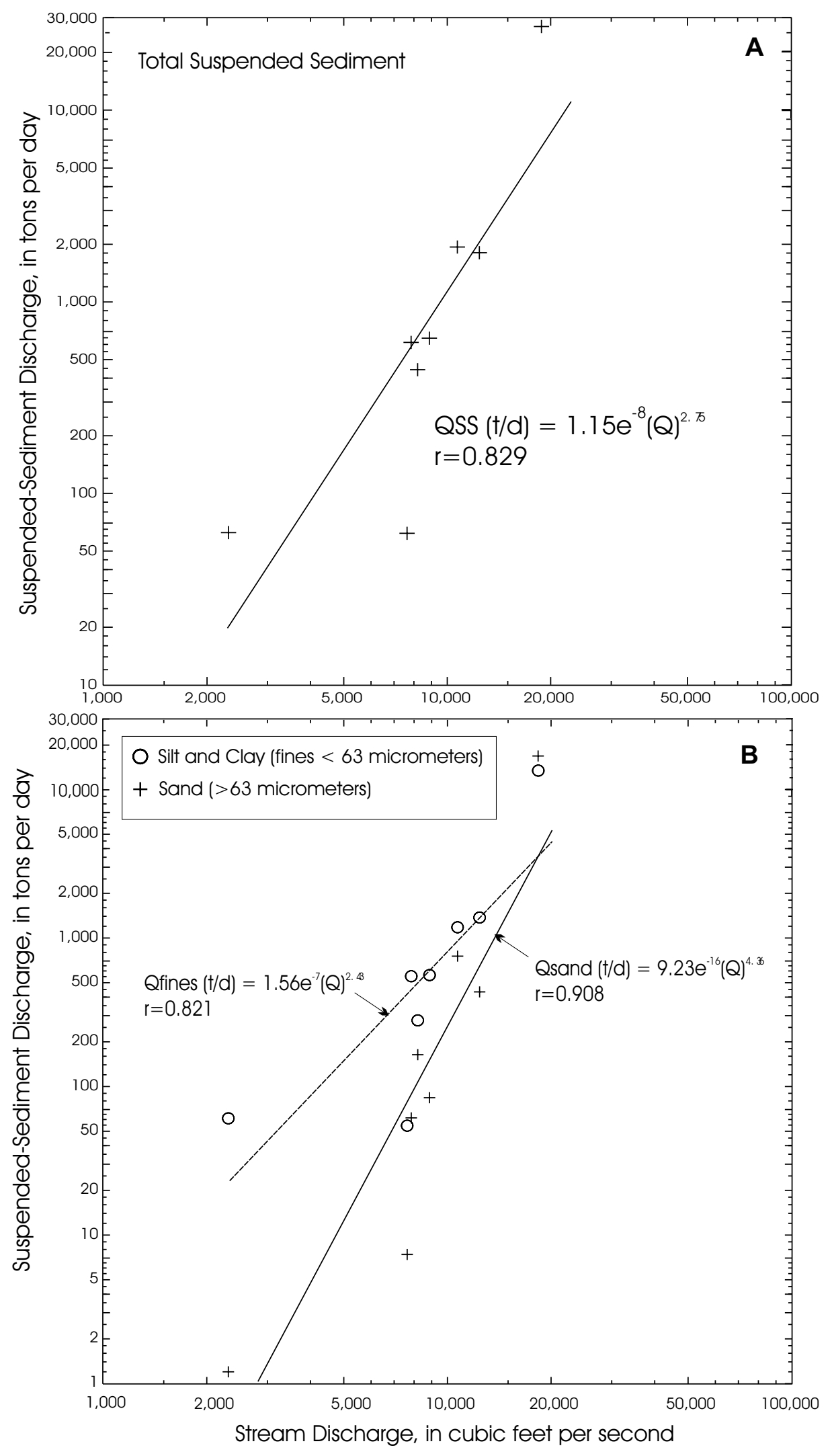

Figure 9. Sediment-transport curves for (A) total suspended sediment, and (B) suspended silt and clay and suspended sand, Coeur d'Alene River near Harrison, Idaho 


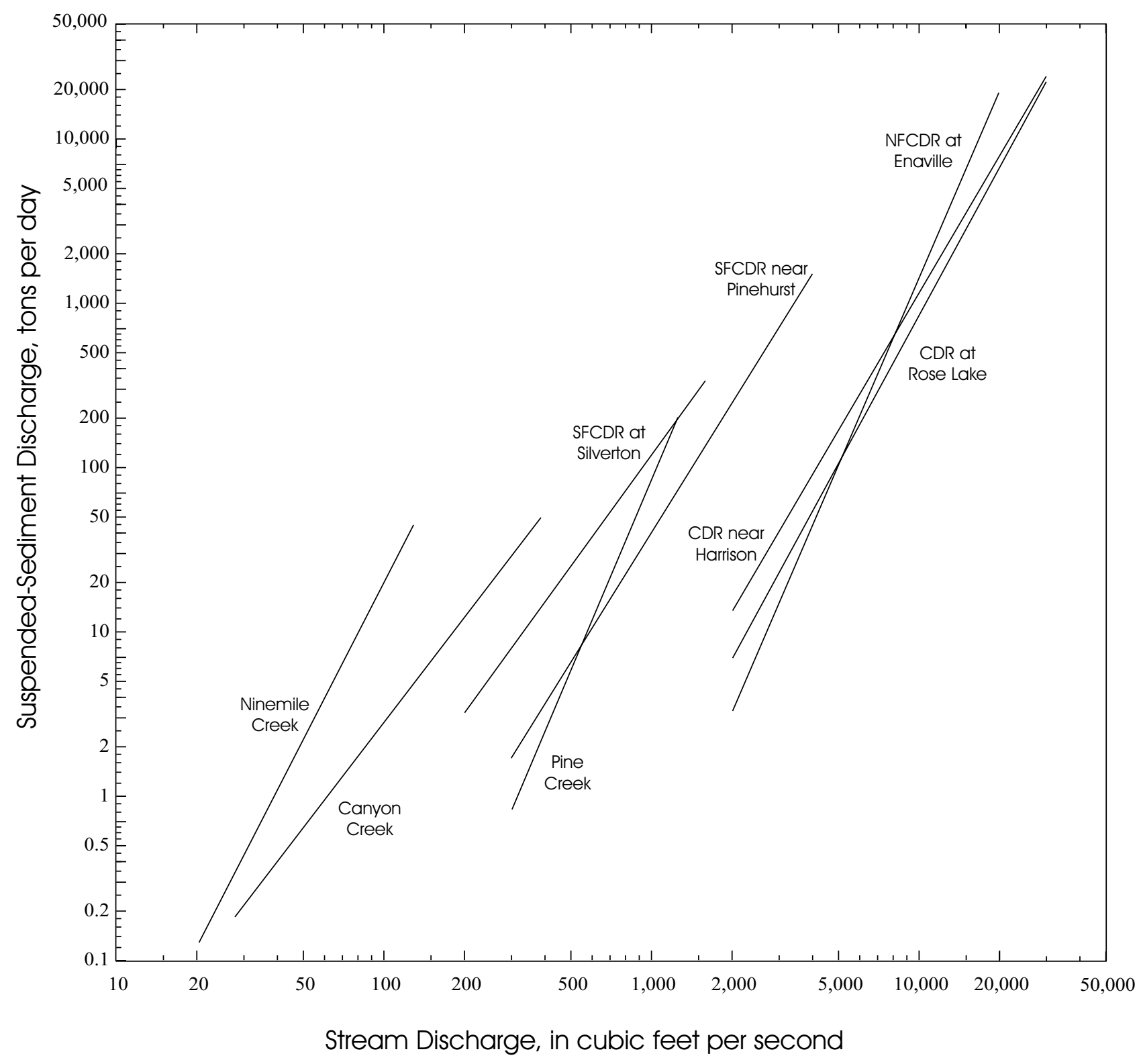

Figure 10. Sediment-transport curves for total suspended sediment at eight stations, Coeur d'Alene River Basin, Idaho 

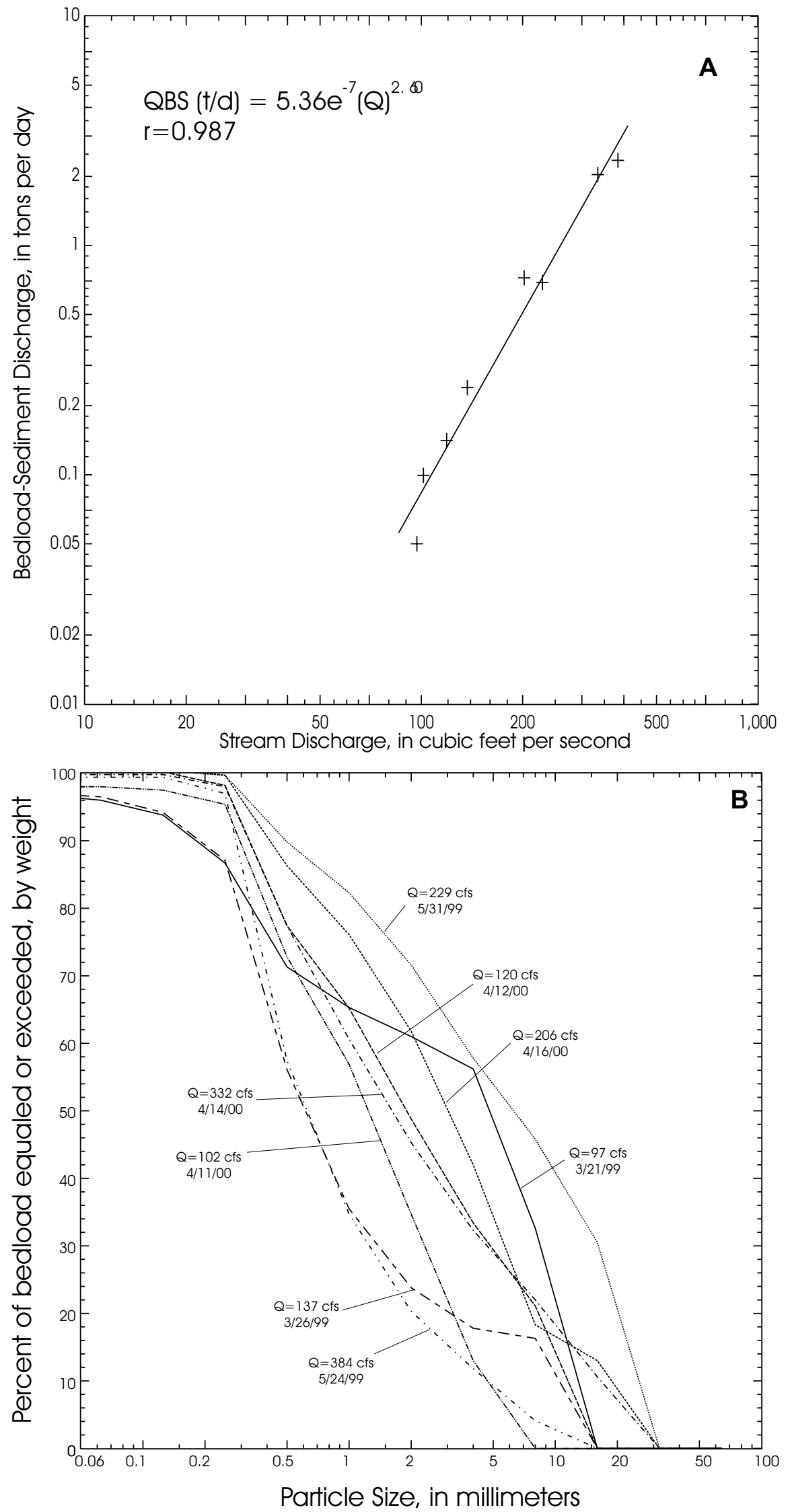

Figure 11. (A) Sediment-transport curves and (B) particle-size distribution of bedload sediment, Canyon Creek above mouth at Wallace, Idaho 

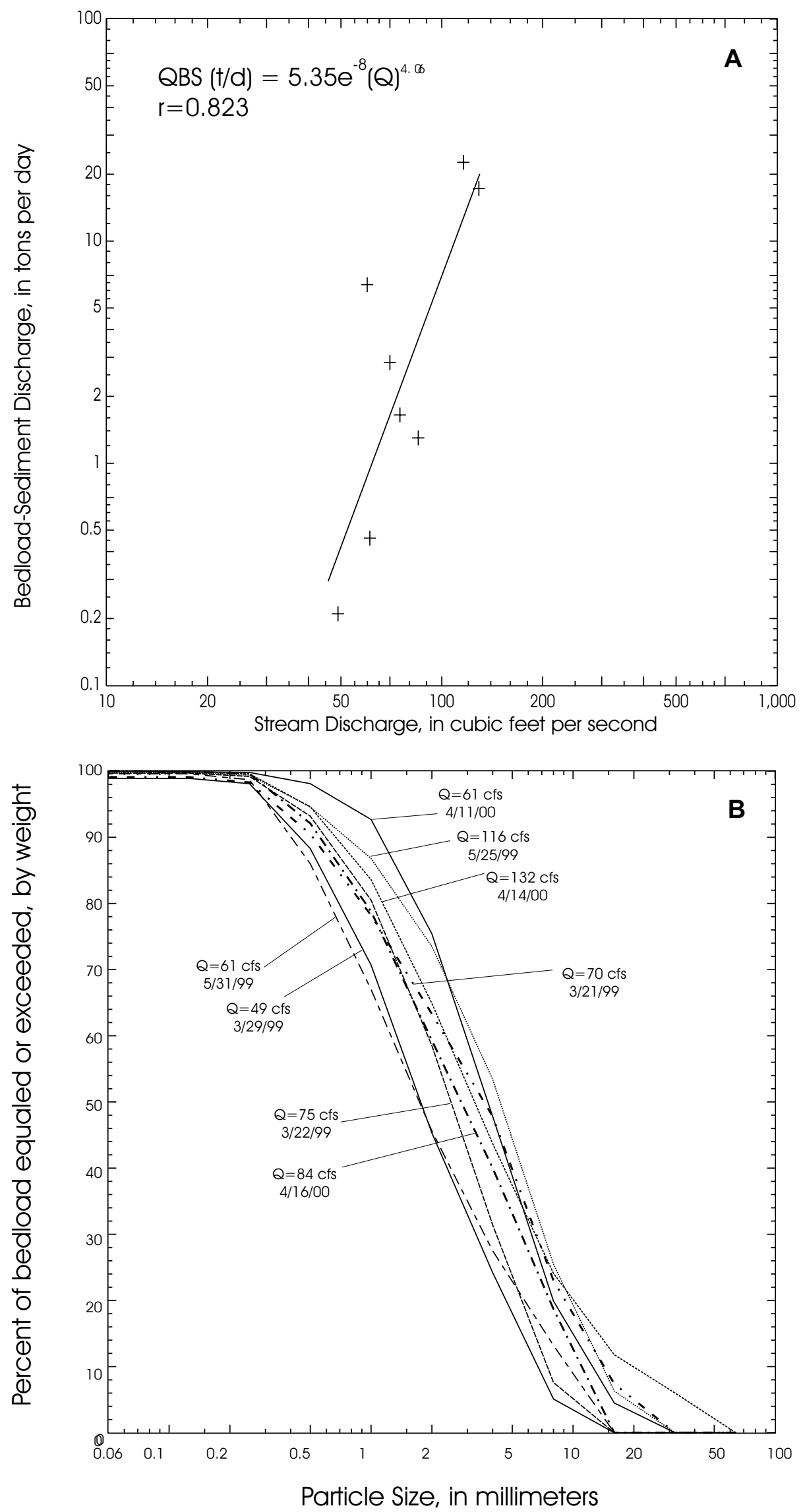

Figure 12. (A) Sediment-transport curves and (B) particle-size distribution of bedload sediment, Ninemile Creek above mouth at Wallace, Idaho 

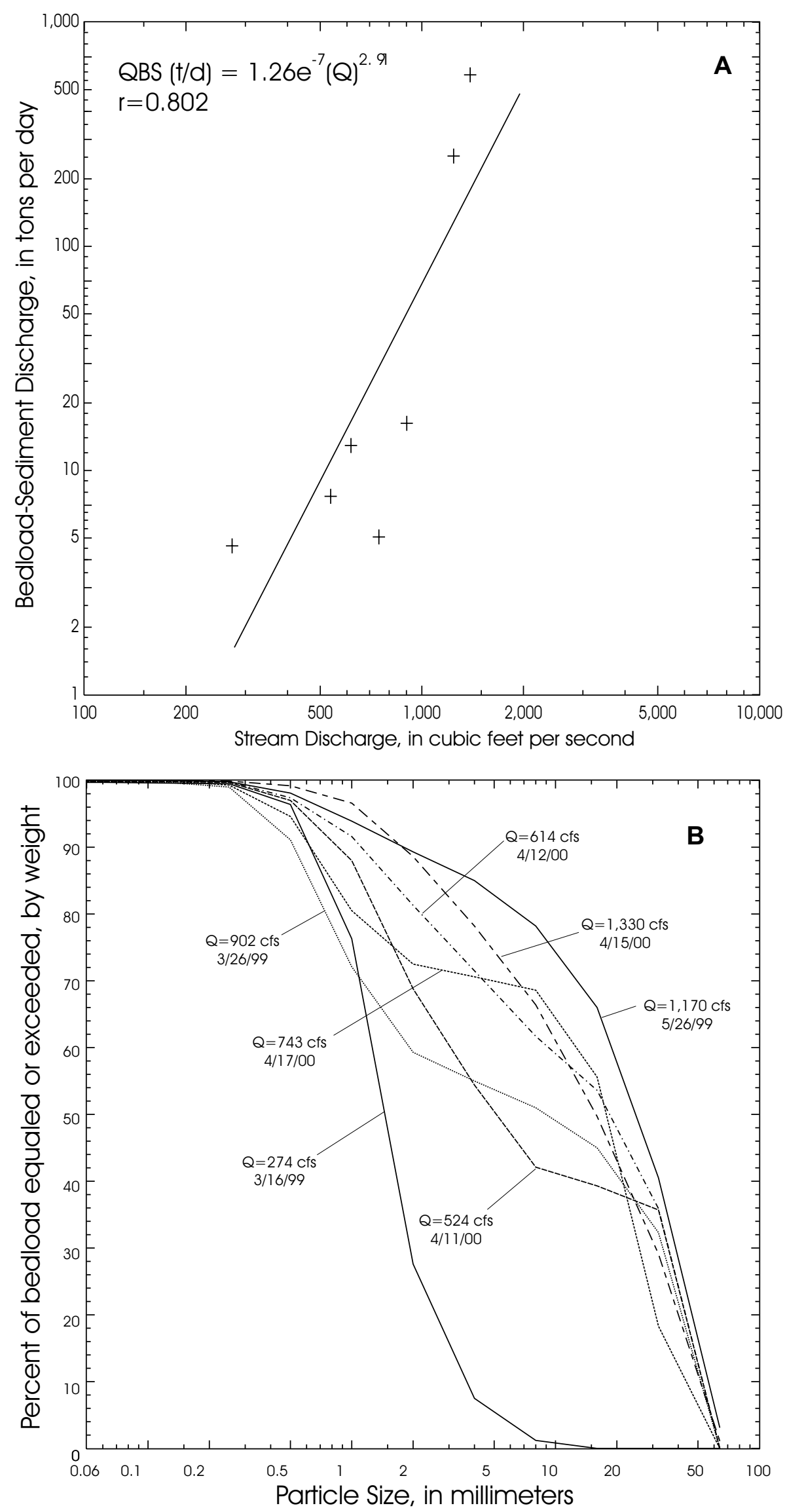

Figure 13. (A) Sediment-transport curves and (B) particle-size distribution of bedload sediment, Pine Creek below Amy Gulch near Pinehurst, Idaho 

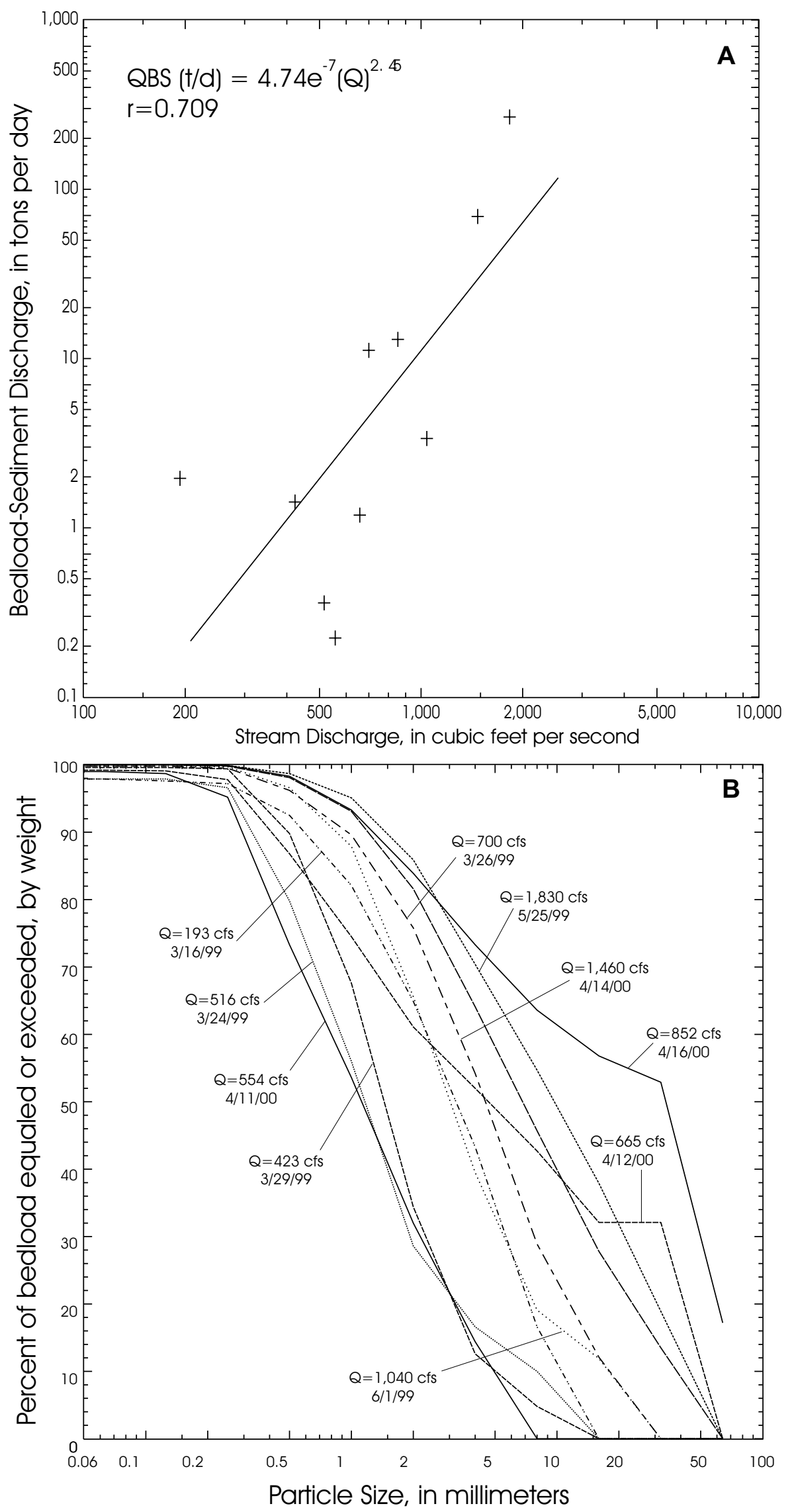

Figure 14. (A) Sediment-transport curves and (B) particle-size distribution of bedload sediment, South Fork Coeur d'Alene River at Silverton, Idaho 

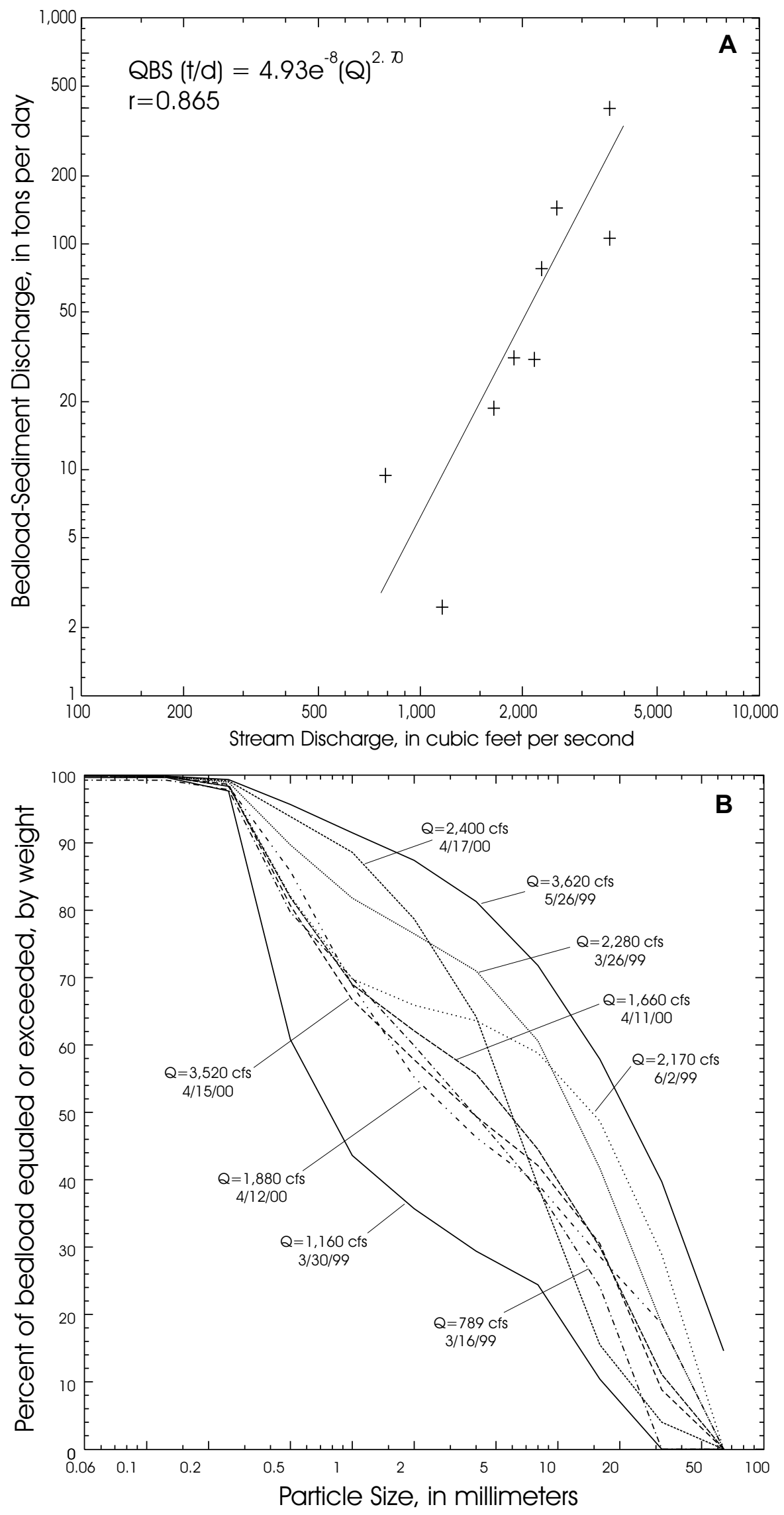

Figure 15. (A) Sediment-transport curves and (B) particle-size distribution of bedload sediment, South Fork Coeur d'Alene River near Pinehurst, Idaho 

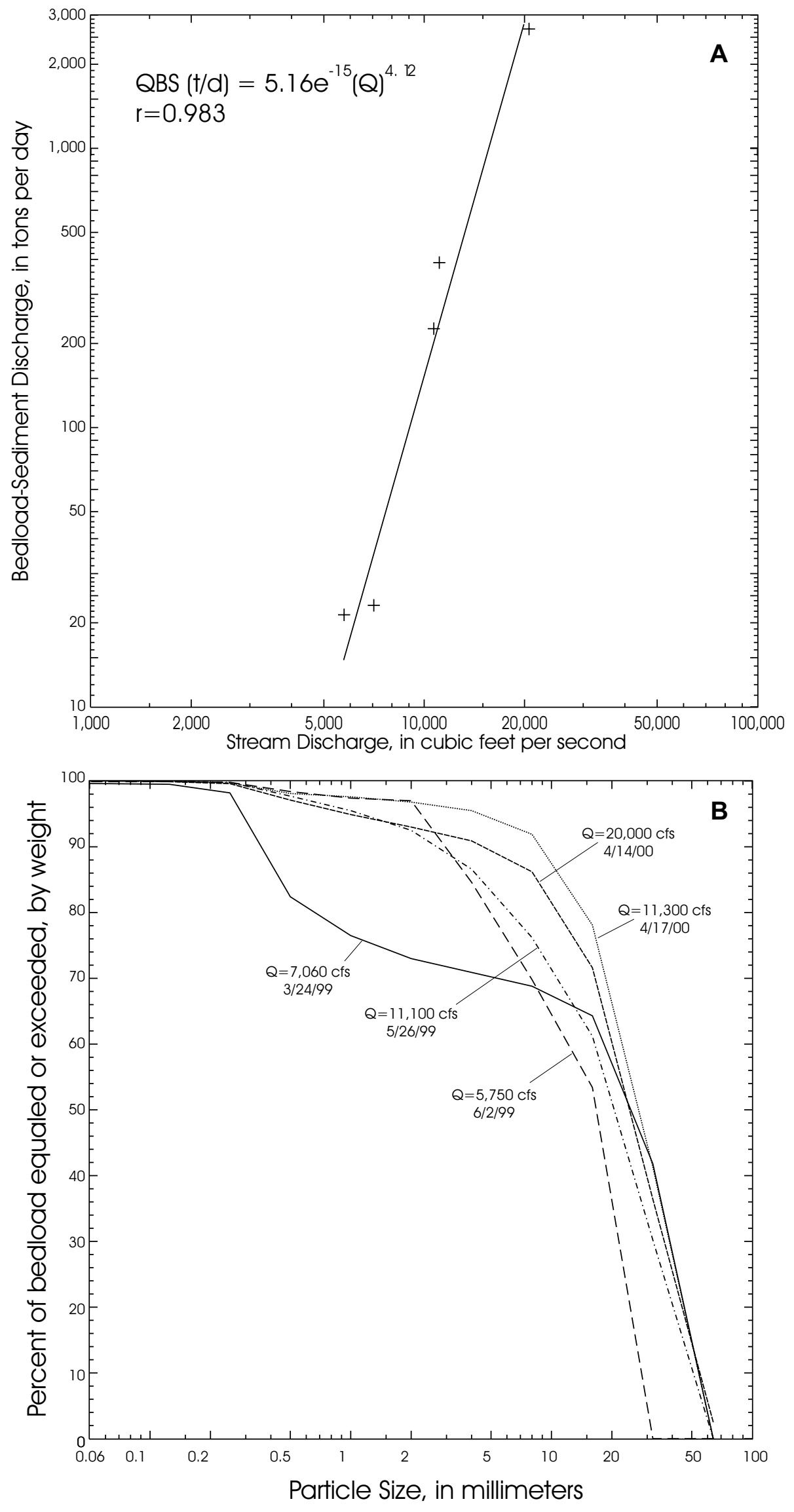

Figure 16. (A) Sediment-transport curves and (B) particle-size distribution of bedload sediment, North Fork Coeur d'Alene River at Enaville, Idaho 

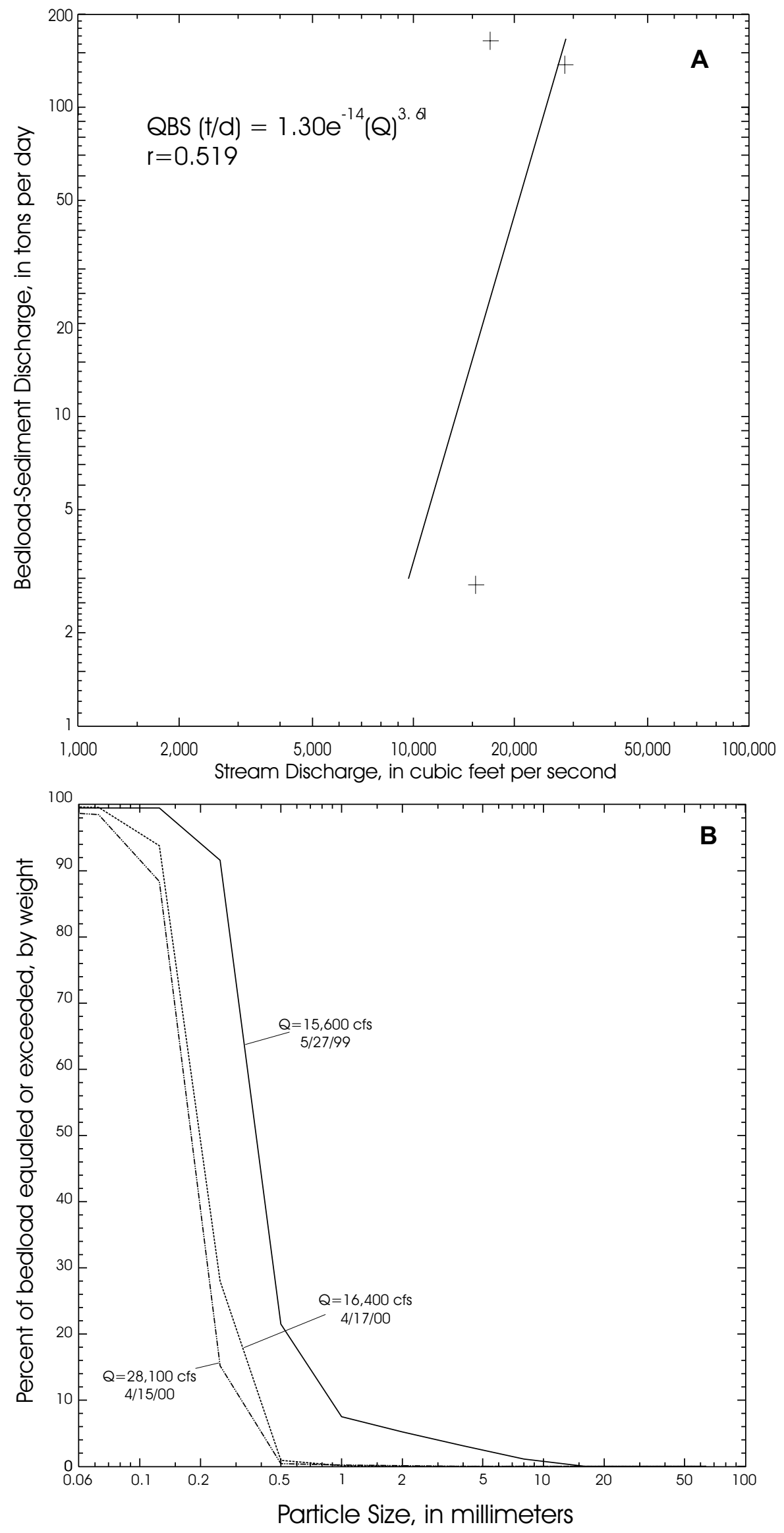

Figure 17. (A) Sediment-transport curves and (B) particle-size distribution of bedload sediment, Coeur d'Alene River at Rose Lake, Idaho 


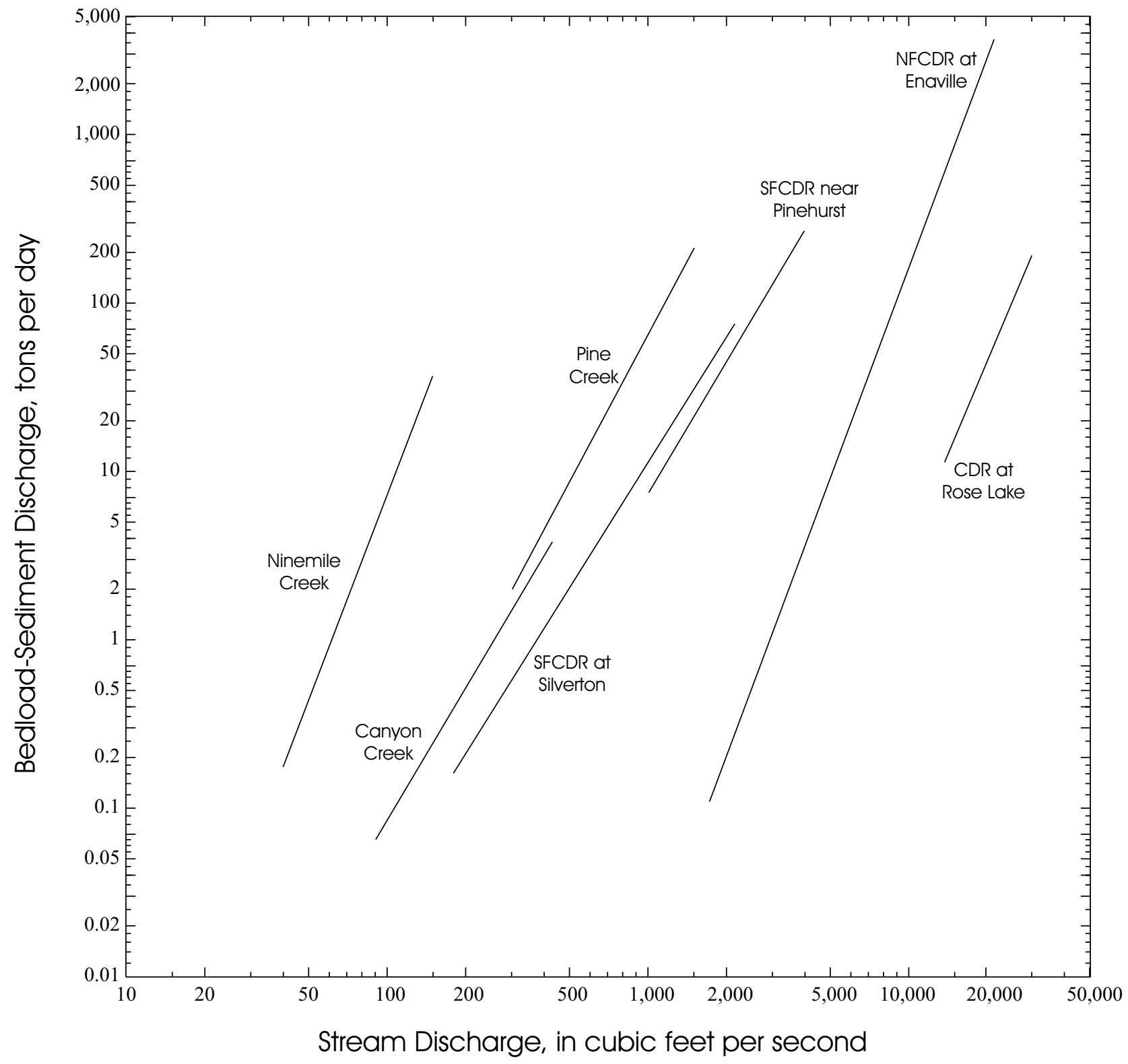

Figure 18. Sediment-transport curves for bedload sediment for seven stations, Coeur d'Alene River Basin, Idaho 

Printed on recycled paper 